\title{
Impact of Earnings Performance on Financial Stability of Selected Banks in Nigeria
}

\author{
Yakubu, Bala Zakari \\ Department of Accountancy, Nasarawa state Polytechnic, Lafia
}

\begin{abstract}
This paper assesses the impact earnings performance indicators on the financial stability of banks in Nigeria. The study area composed of twelve selected deposit money banks listed on Nigerian Stock Exchange (NSE) covering the period of five years from 2014 to 2018. Description statistics was used to analyse the study variables, whereas correlation technique has been utilized to evaluate the impact of firm earnings performance on the financial stability of the banks. It is found that there is sturdy link between the firms' earnings performance and the financial stability. It is additionally reveal that share worth of Banks in Nigeria be explained more considerably by the amount further than the banks' ancient measures of earnings.
\end{abstract}

Keywords: Earnings performance, Economic value added, Earnings per share, Financial stability.

\section{INTRODUCTION}

$\mathrm{T}$ The earnings information indicates the extent to which a corporation engaged in worth additional activities over a given period of time. It conjointly shows the signal of direct resource allocation within the capital market. In determining the attractiveness of a particular stock, investors and financial analyst usually give emphasis to earnings as they indicate the expected future dividends and the future growth as well as the expected capital appreciation of a given corporation. The present worth of future earnings determines the worth of company's stock. Thus, corporations with good earnings prospects can generally have the next market share value than those with poor earnings. The ability of a firm to generate profit in the future plays a significant role in its stock price determination. The firm's value has a direct relationship with its future earnings, hence the executives should be able to comprehend their effects on accounting and they should be able to manage their earnings so as to make the best possible decisions for the company (Rahman, Moniruzzaman \& Sharif, 2013).

It is rightfully to say that the rate earnings and the volume of earnings of a firm are indicators of efficiency in the allocation and utilization of the firm's resources. Seetharaman and Raj (2011) opines that earnings of a company reflect not only in the market price as shown in the capital market information, but also in the price earnings ratio, dividend cover, dividend and earnings yields among others. To Maradum (2010), corporate organizations existence is indicated by the company's earnings and they are often the unique and most important determinant of stock price.
In recent years, financial stability problems are receiving priority attention from policy makers and other stakeholders round the world as this has a direct bearing with the firm's earnings performance. The East Asian financial crisis of late 1990s made the World Bank and the International Monetary Fund (IMF) to introduce the Financial Sector Assessment Program (FSAP) in 1999 to regularly assess the strengths and weaknesses of financial systems in the affected member countries.

In addition, many international forums such as the Financial Stability Forum, Basle Committee on Banking Supervision, Financial Stability Institute, Committee on the Global Financial System, Committee on Payment and Settlement Systems, International Association of Insurance Supervisors, International Accounting Standards Board, International Organization of Securities Commissions and the International Association of Deposit Insurers among others surface or become more active and dedicated to monetary stability problems. On the other hand, Counterparty Risk Management Policy Group exists for the private sector organization dedicated to fostering financial stability.

Many countries of the world through their apex banks (central banks) and restrictive authorities (including the Central Banks of some countries) have conjointly taken financial stability issues more serious, by putting in place an operational financial stability Departments and introducing the regular publication of Financial Stability Reports, focused on assessing potential risks to financial stability (Cihak, 2006 and Oosterloo, Haan, \& Jong-A-Pin, 2007).

\section{Statement of the Problem}

Financial stability as a key factor is not a straightforward indices to measure given the reciprocality and also the complicated interactions of various parts of the financial system among themselves and with the real economy. This is further made complex by the time and cross-border dimensions of such interactions. Researches from apex banks of various countries and scholars around the world have attempted to capture conditions of financial stability through various indicators of financial system vulnerabilities aimed at developing a single aggregate measure that could indicate the degree of financial fragility or stress so as to: better monitor the degree of financial stability of the system; future expectation of the roots and causes of financial stress to the system and effectively communicate the impact of such conditions. No literature has tried to link earnings potentials 
of firms with their financial stability. Thus this study is developed as a need to bridge this data gap using listed banks in Nigeria.

\section{Objectives of the Study}

The main objective of the study is to evaluate the impact of firms' earnings performance on the financial stability. Specifically, this study seeks to:

1. Assess the impact of Earnings Per Share (EPS) on the financial stability of Nigerian banks.

2. Assess the impact of firms' Economic Value Added Per Share (EVAPS) on the financial stability of Nigerian banks.

\section{Hypothesis}

The null hypotheses $\left(\mathrm{H}_{0}\right)$ are formulated and stated as below:

- $H_{01}$ Earnings Per Share (EPS) has no effect on the financial stability of Nigerian Banks

- $H_{02}$ Economic Value Added per Share (EVAPS) has no significant effect on financial stability of Nigerian banks.

\section{LITERATURE REVIEW}

Over the years, the wellbeing, growth and successful operation of banks has attracted the interest of different academic researchers, managers and other professionals. This is cardinal since identifying the key success factors of financial performance allows for designing well- informed policies that may significantly improve the overall performance of the sector. A number of studies have examined the determinants of banks"e performance in many countries around the globe. For instance, Almazari (2013), Almumani (2013), Ani, et.al (2012), Aremu, et.al (2013) among others. Although a lot of studies and literatures which examines the determinants of banks financial performance exist, these studies show different and even contradictory results.

\section{Earnings Performance}

Earnings is the rally point for most stakeholders of any given business oriented organization; and it is one of the major reasons for the existence of business enterprises. It remains one of the major routes of assessing firm's well-being and to know whether it will be able to meet financial obligation of all interested parties; and as well an indication for possible payment of dividend. Earning constitute the most important section of entity which indicates the strength, weakness and financial stability of any firm, thus serves as the indicator of firm's financial health and strength which in turn is a barometer to measure the wealth of stockholders.

Prospective investors are attracted to invest in a company through the information on company's earnings with continuous improvement in their stock prices. As earnings serve as key indicator of stock prices, organizations tend to undertake specific projection of their earnings. Management employs different majors and strategies that are lawful and sometimes unlawful to attain targeted earning goals. This development or strategy is known as earnings management.

In a simple term, earning performance is a way in which shares earn dividends. It is a yielding pattern of stock in relation to dividend or how well a particular stock contributes in the realization of firm's dividends.

\section{Earnings Performance Measures and Stock Returns}

The changing nature of business and management performance has pushed the need to build a more effective and structured financial measurement. Thus effective performance measurement is believed to be of crucial importance in ensuring the successful implementation of an organization's strategy (Azam \& Rasool, 2019).

Several studies have confirmed that stock returns are positively related to corporate governance and performance measures. The relationship between corporate governance and long-term equity returns, firm value and accounting measures of performance was carried out by Gompers, Ishii and Metrick (2003). The findings of the study show that a well-governed firm has higher equity returns and also command higher values as compare to poor governed firm. Moreover, the financial statements of a well governed firm show a better operating performance when compared with poorly governed firms. Brown and Caylor (2005) study revealed that a wellgoverned firm is relatively more profitable and more highly priced in terms of their share, and also pay out more cash dividend to their shareholders.

There are various accounting-based performance measures that are produced by a number of consulting firms to assist firms design, develop and implement compensation schemes aimed at increasing shareholder value. Myers (1997) summarizes some of the techniques to include: Stern Stewart's Economic Value Added (EVA), Holt's Cash Flow Return on Investment (CFROI), Boston Consulting Group's Total Business Return (TBR), McKinsey's Economic Profit, and LEK/ALcar's Shareholder Value Added (SVA) among others.

The ascertainment of the mutual relationship between measures and stock returns has been the subject of many studies, as the avowed goal of these new performance measures is to improve the share owner value. However, early study by Gjesdal (1981) does not notice a robust connection the study variables stock returns and performance measures. No measure of performance could ever have a higher statistical correlation with stock returns than the return itself. If this correlation were the sole goal, corporations ought to employ their stock price to ascertain compensation and ignore all alternative measures. Notwithstndanding, stock returns may not be accurate and sometimes misleading. A Standard principal-agent model was employed by Garvey and Milbourn (2000) in which contracts are based on any two accountingbased performance measures plus the stock price to examine 
which performance measures best capture managerial contributions to value. They discovered that stock prices provide a laudable noisy measure of managerial value-added and that the simple correlation between EVA or earnings and stock returns is a fairly reliable and valuable instrument for shaping managerial incentives. They additionally calibrate the theoretical improvement in incentive contracts from optimally using EVA in addition to accounting earnings and empirically estimate the value added from EVA by firm. These estimates are positive and vital in predicting which firms have actually adopted EVA as an internal performance measure.

One of the drawbacks in utilizing the earnings-based numbers like net income and cash flow from operations to evaluate the firm's performance is that they solely show the company's interest expenses (Nuttawat, Robin \& Yi, 2008). The value of equity capital is unheeded. As a result, it's tough to ascertain whether or not the firm has created wealth for its shareholders. Moreover, the correlation between earnings and stock returns is comparatively low. Sloan (1993) demonstrates that earnings solely mirror however business-specific factors affects modifications prices of stock and are unable to mirror however stock prices change with reference to external environmental factors. Additionally to earnings, securities market performance measures like stock worth performance, return on equity (ROE), and earnings per share (EPS) are thought-about to supplement earnings-based performance measures for evaluating shareowner value.

A number of studies were conducted to ascertain whether EVA is closely associated with stock returns than the usual traditional stock market performance measures such as return on equity, return on assets and earnings per share. Lehn and Makhija (1997) carried out a study based on a database of 452 large United States companies during the period of 19851994. The study objective is to examine the value relevance of accounting profit performance measures as return on equity, return on assets and stock performance measures (RET), and value-based performance measures (EVA and MVA), respectively. Their finding show that there is a significantly positive correlation between value-based performance measures and stock returns and conclude that EVA is a more effective performance measure than the traditional accounting based measure.

Despite this, some empirical researches showing EVA superiority over the traditional accounting performance measures in relation to stock returns is still controversial. This is confirmed by a number of previous studies showing that traditional earnings-based performance measures are dominant in the firm's performance measurement. Biddle et al. (1997) argue that conventional accounting profit rates such as earnings per share, return on assets and return on equity are better measure of firm performance than EVA earnings dominate despite EVA role in explaining stock returns in the relative information content test. Dodd and Chen (1996) using a sample of 566 United States companies over the period of 1983-1992, investigate the association of EVA, EPS, ROE and ROA with stock returns. Their result show that using unadjusted accounting measures earlier mentioned have greater association with stock returns than EVA. The study by Copeland, Dolgoff and Moel (2004) further confirm the superiority of the conventional or traditional measures to the EVA measure given similar results in their findings. Another dimension was an extension of performance measurement in which the EVA-to-market value (EVAM) ratio was introduced by Leong, Pagani and Zaima (2009) to ascertain whether portfolios created by utilizing the EVAM ratio will generate higher returns than portfolios formed with earningsprice (EP) ratio and book-to-market (BM) ratio and fail to find any statistical difference among them.

\section{Financial Stability}

The global financial system is more resilient and better placed to sustain financing to the real economy as a result of the G20 regulatory reforms in the aftermath of the 2008 global financial crisis.ban interesting aspect of the latest financial crisisnis that not only did very efficient banks fail, but that they failed despite them complying with the Basel rules (Konstantinos, 2018). In particular, greater resilience of major banks at the core of the financial system has allowed the system to date largely to absorb rather than amplify the current macroeconomic shock (Financial Stability Board, 2020).

Financial stability as a financial concept has no universal definition and even has no generally accepted method of measurement given the interdependence and the complex interactions of different elements of the financial system among themselves and with the real economy. The narrow definition is relatively simple to formulate, but fails to capture the positive contribution of a well-functioning financial system to overall economic performance. Indeed, broader definitions of financial stability encompass the smooth functioning of a complex nexus of relationships among financial markets, infrastructures and institutions operating within the given legal, fiscal and accounting frameworks. Such definitions are more abstract but are more inclusive of the macro-economic dimension of financial stability and interactions between the financial and real sectors. From this perspective, European Central Bank (2007) defined financial stability "a condition in which the financial system comprising financial intermediaries, markets and market infrastructure - is capable of withstanding shocks and the unravelling of financial imbalances, thereby mitigating the likelihood of disruptions in the financial intermediation process which are severe enough to significantly impair the allocation of savings to profitable investment opportunities." Strictly speaking, financial stability is a financial system that is stable, secured, safe, steady, sound and in the absence of excessive volatility, stress or crises.

In the words of Crockett (1997) financial stability is "that the key institutions in the financial system are stable, in that there is a high degree of confidence that they continue to meet their 
contractual obligations without interruption or outside assistance; and that the key markets are stable, in that participants can confidently transact in them at prices that reflect the fundamental forces and do not vary substantially over short periods when there have been no changes in the fundamentals". Implicitly, this definition takes account of the condition of financial intermediaries and markets, but not financial infrastructure. Also, in distinction to another writers (e.g. Davis 2001 and Allen and Wood, 2006), the statement considers periods of asset price volatility as evidence of instability. Finally, it contends that financial stability exists if the financial system can continue to function normally without "outside assistance". Hence, it excludes situations where financial instability is only avoided through the provision of financial or other kinds of support to financial institutions by the regulatory or political authorities.

Lager (1999) posits that "the objective of financial system stability could therefore be defined, in broad terms, as the avoidance of disruptions to the financial system that are likely to cause significant costs to real output". He went further to say that "such disruptions might have their origins in difficulties facing financial institutions or in disturbances in financial markets". Again, there is emphasis on the impact of financial instability on the real economy and recognition is also given to disruptions in financial markets (in addition to cases of distress in financial intermediaries).

According to Foot (2003), “...we have financial stability where there is: (a) monetary stability; (b) employment levels close to the economy's natural rate; (c) confidence in the operation of the generality of key financial institutions and markets in the economy; and (d) where there are no relative price movements of either real or financial assets within the economy that will undermine (a) or (b)". This is one of the few definitions which mention monetary stability as an essential part of financial stability. Foot's definition is notable in interpreting the linkage with the real sector in terms of proximity to the natural rate of employment levels. It also highlights the importance of "confidence" in the operation of the financial system, a position similar to the arguments of Large (2003) who described financial stability mainly in terms of maintaining confidence in the financial system.

Padoa-Schioppa (2002) contends that "...financial stability is a condition where the financial system is able to withstand shocks without giving way to cumulative processes, which impair the allocation of savings to investment opportunities and the processing of payments in the economy". The emphasis here is on the shock-absorbing capacity or resilience of the financial system, so that it can continue to carry out its essential functions of resource allocation and provision of payments services. The reference to payments services here is important because like disruptions to the intermediation function, disturbances to the payments system have the capacity to inflict adverse effects on the level of economic activity (Davis, 2001).
Schinasi (2004) offers the following definition: "A financial system is in a range of stability whenever it is capable of facilitating (rather than impeding) the performance of an economy and of dissipating financial imbalances that arise endogenously or as a result of significant adverse and unanticipated events". This statement is unique in viewing financial stability as a continuum, rather than a single, static condition (ibid, p. 6). This implies that financial systems operate within a corridor, with stability and instability at opposite ends. Movements towards the "unstable" end of the corridor could then be due to an accumulation of imbalances (or vulnerabilities) within the financial system or because of exogenous shocks. Like some writers cited earlier, Schinasi points out that instability should refer to cases where the financial system impedes the normal functioning of the real economy.

As many central banks established Financial Stability Departments and began publishing Financial Stability Reports, they have also adopted specific definitions in order to provide some guidance to their objective of safeguarding financial stability. European Central Bank (2011) define financial stability as a condition in which the financial system - which comprises financial intermediaries, markets and market infrastructures - is capable of withstanding shocks and the unraveling of financial imbalances. This mitigates the likelihood of disruptions in the financial intermediation process that are severe enough to significantly impair the allocation of savings to profitable investment opportunities.

Central bank of Bahrain (2007) sees it as a situation where the financial system is able to function prudently, efficiently and uninterrupted, even in the face of shocks. Central bank of Nigeria (2013) defines financial stability is the resiliency of the financial system to unanticipated adverse shocks, while enabling the continuing smooth functioning of the financial system's intermediation process.

\section{Assessment of Financial Stability}

Policymakers and educational researchers have centered on a variety of quantitative measures in order to assess financial stability. The set of Financial Soundness Indicators (FSI) developed by the IMF (IMF (2006)) are examples of such indicators, as are the monitoring variables used in Hawkins and Klau (2000), Nelson and Perli (2005) and Gray et al (2007) which focus on market pressures, external vulnerability and banking system vulnerability. Blaise and Kaushik (2015) identified six main sectors to include: Real economy- measures the GDP growth; corporate sectormeasures corporate leverages (debt to equity); Household sector-measures household assets (financial real assets); external sector-measures real exchange rate, foreign exchange reserve, current account/capital flows; financial sectormeasures monetary aggregates, growth in the bank credits, and financial markets-measures change in equity indices, market liquidity etc. 


\section{Empirical Evidence on Earnings Based Performance Measure}

Researches into the link between capital markets and financial statements has its origin in the publication of Ball and Brown 1968 where they first examined the relationship between earnings and stock prices (Kothari, 2001). Since then many other publications have contributed to the field demonstrating a positive relationship between earnings and stock returns. Furthermore, using different methodologies, a considerable number of studies have been conducted investigating the relationship between accounting earnings and stock returns. To refer to some: Cheng, Cheung and Gopalakrishnan (1993) evaluated the usefulness of operating income (OI), net income (NI) and comprehensive income (CI) based on a sample that averaged 922 firms a year for 18 years, they found that OI weakly dominated NI, and that both OI and NI dominated CI in information content.

An investigation into the relationship between stock returns, earnings, and a variant of earnings called DVFA4 on the German market conducted by Booth, Broussard and Loistl (1997), concluded that both types of earnings were associated with stock returns with the latter being more significant. Vafeas, Trigeorgis and Georgiou (1998) provided evidence for the Cyprus stock market and suggested that earnings levels as well as changes in earnings are important in explaining stock returns in an emerging stock market. King and Langli (1998) examined accounting figures across Germany, Norway and the UK. They found, among others, that accounting book value and EPS were significantly related to current stock prices across all three countries with Germany scoring the lowest relation and UK reaching the highest one.

Graham and King (2000) examined the relationship between stock prices and accounting earnings and book values in six Asian countries: Indonesia, South Korea, Malaysia, the Philippines, Taiwan, and Thailand. They found differences across the six countries in the explanatory power of book values per share and residual earnings per share for firm values. Explanatory power for Korea and the Philippines was relatively high while that for Taiwan and Malaysia was relatively low. They also provided evidence suggesting that in all six countries residual earnings per share has less explanatory power than book value per share in most years.

Jindrichovska (2001) reported a statistically significant relationship between returns and accounting data for the developed Czech stock market, supporting the evidence from previous studies such as Kothari and Zimmerman (1995) that stock prices lead earnings.

\section{Empirical Evidence on Value-Based Performance Measures}

The overall results of the value relevance literature counsel that accounting-based information can potentially influence stock prices. The empirical literature also claims that earnings generally dominate most other measures in explaining stock returns. However, the more recent literature (Grant, 2003; Abate, Grant and Stewart, 2004) suggested that earnings should not be relied upon, since they have little direct relationship to wealth creation. Thus, research into information content of other variables such as cash flows, has increased largely for two reasons: the apparent limitations in earnings numbers, and the increased need and demand for analysts and investors to correctly identify the value of the companies.

Dimitrios, Zeljko and Nikolaos (2006) pointed out that while traditional accounting performance measures are popular measures for financial performance measurement, they are often under severe critique since they do not take into consideration the cost of capital and moreover, they are influenced by accrual based accounting conventions. On the other hand, modern value- based measures are promoted as the measures of a company's real profitability. Especially, EVA proponents have argued that EVA and stock prices appear to have a trend to move together. Moreover, they have asserted the superiority of information contained in EVA when it is compared to traditional accounting figures. Those claims have been empirically tested by many scholars such as Stewart (1991), Lehn and Makhija (1997), Milunovich and Tseui (1996) and Worthington and West (2001) clearly suggested the superiority of EVA compared to earnings and other accounting performance measures in explaining stock returns.

Contradictory and mixed results were obtained as regard the study on EVA. Chen and Dodd (1997) extended the previous research and examined the explanatory power of EPS, ROA, ROE, RI, and four EVA related measures. Firstly, they found that improving EVA performance is associated with higher returns. However this association is not as strong as suggested by EVA proponents.

Other scholars such as Forker and Powell, 2004; Worthington and West, 2004 used different methodologies provided totally different results than those reported by Biddle, Bowen and Wallace (1997). Worthington and West (2004) using the same sample but changing the methodology found that EVA is more associated with stock returns than earnings. Forker and Powell (2004) also, using Shiller (1981) methodology revisited Biddle, Bowen and Wallace (1997) study and provided reverse results. They showed that investors' factor of cost of capital into equity pricing and residual-based metrics, such as EVA, are superior to traditional accounting metrics in providing a basis for investors to confirm or revise their expectations in the valuation process.

Turvey, Lake, Duren and Sparing (2000) studied the relationship between EVA and stock market returns for a sample of 17 publicly traded food companies in Canada. The key finding was that no relationship could be found between the two. Keef and Rush (2003) examined both theoretically and empirically the link between EVA and stock price reaction. They found the results of Turvey et al. (2000) as expected, but moreover, they considered the EVA concept as an enigma. In light of the findings and the arguments of 
Turvey et al. (2000) and Keef and Rush (2003), Sparling and Turvey (2003) examined the relationship of EVA and shareholder returns and found an extremely weak correlation.

Many other studies reported the weak correlation of RI metrics with stock returns. Peterson and Peterson (1996) provided evidence that EVA type measures do not provide much more information than stock prices. Stark and Thomas (1998) examined the UK market and concluded that the relationship between RI and market value is by no means perfect. Günther, Landrock and Muche (2000) in examining the Germany stock market, could not prove that value-based measures (EVA, CVA, DCF and Tobin's Q) outperform traditional accounting-based measures (ROS, ROI, and ROE). Goetzmann and Garstka (1999) found that long-term survival of companies may be related to accounting earnings, and more, simple EPS does as well or better than EVA at explaining differences across companies and at predicting future performance. Finally, Kramer and Peters (2001) also reported the weak correlation between EVA and MVA.

As for the Greek capital market, there is almost no evidence concerning the relevance of value-based measures on performance measurement.

\section{Economic Value Added}

Economic Value Added, or EVA is one of the popular tools that bankers can use to measure the financial performance of their bank (Azam \& Rasool, 2018). EVA helps management to conduct internal goal-setting. Economic value added plays a significant role for assessing the financial position of the business entity in an effective manner (Hmad, Alam \& Yameen, 2019). It measures the company's financial performance based on the residual wealth calculated by deducting its cost of capital from its operating profit, adjusted for taxes on a cash basis. It helps to capture the real economic profit of a company. Priyanka and Sudha (2020) describe economic value added is a measure of economic profit, and is calculated as the variation among the net operating profit after tax and the opening cost of invested Capital. This opening cost is determined by the weighted average cost of Debt and Equity Capital ("WACC") and the amount of Capital employed. EVA estimates the economic profit of an enterprise along with the factor of value creation, and uses discounted future cash flows to generate profit (surplus return) after the earnings are distributed to the investors (Ejaz, Tashfeen, Younas \& Naeem, 2018)

Singh and Garg (2004) have compared some selected financial variables like ROCE, EPS, ARNW, MVA and NPV with EVA. They observed in almost all cases, the positive relationship has been established between the variables under reference. The different correlation matrix tables have reveals that EVA is also giving the results in the same direction for the rationale underlying. During the multiple regression analysis in their study, it became apparent that EVA was the single largest and most consistent variable, which has a decisive role in predicting the MVA. Their study concludes that the relationship between EVA and MVA is statistically significant.

The claim that EVA is the main driver for shareholder value has been empirically tested by a number of US studies, giving rather mixed results. A number of these studies report either poor or no statistical relation between EVA and stock return, or between EVA and market value ( Rafrini \& Elsa, 2016).

Eljelly and Alghurair (2001) test the association between stock returns and wealth creation (as measured by Market Value Added, MVA) on the one hand and various performance measures of joint stock companies in Saudi Arabia. These measures include traditional accounting measures; Earning Per Share (EPS), Return on Equity (ROE), and Cash Flow (CF), as well as a relatively recent measure, the Economic Value Added (EVA). Their study reveals strong links between various traditional accounting measures and show that those measures give similar indication of a company's overall performance. The results indicate that MVA and stock returns are associated with traditional accounting measures, but not with EVA. However, EPS is found to dominate other measures of performance with respect to its association with stock returns and MVA

\section{Theoretical Base}

The neo-classical economic theory known as the dominant model indicates the main objective of a company is to maximize profits for shareholders by creating value. On the other hand, Tisdell and Wilson (2012) contend that while the application of neo-classical theory as a means to assess the EVA seems to be straight forward, it is problematic for several reasons. The principal issue is that the neo-classical approach assumes that investors are very well informed and possess all of the knowledge required for perfect decision making. In reality, economic benefits are not captured by neoclassical evaluation. This was the reason that the neo-classical theory was extended to the financial instruments and markets (Shrikant, 2017).

According to agency theory, managers or top management must act to maximize the value of shareholders since they are considered to be the true owners of a firm. Shareholders are prioritized after all other stakeholders like suppliers, debt holders, government agencies, paying taxes and other obligations under state and federal securities laws are satisfied (Frankel \& Rose 1996). Thus, agency theory for shareholder value is still questionable. Agency theory links shareholder value with managerial incentives to avoid conflicts (Roth \& O'Donnell 1996).

Freeman (1984) put forward stakeholder theory with the perspective of strategic management and has been adopted by many organizations as a part of management tool. However, the main weaknesses of stakeholder theory is that it does not focus on shareholder wealth maximization only is bound to serve all the stakeholders in a corporation; and is criticized due to its vagueness and ambiguity. Managers must favor the 
decisions towards all the stakeholders engaged in the company. Firm value cannot be maximized by ignoring the value of shareholders (Jensen 2001). From the critical review, it was found that agency theory and stakeholder theory were facing critiques that made this research to reconcile the originality of agency theory and stakeholder theory favoring the shareholder wealth maximization.

The efficiency of EVA is also criticized in extant studies (Tortella \& Brusco 2003). EVA has been criticized as it does not analyze stock market reaction by the firms. EVA has also been criticized due to the lack of adoption of EVA by the corporations However, after examining the EVA data provided by Stern Stewart \& Co (a management consultant firm), recent literatures like (Gupta \& Sikarwar 2016 \& Nakhaei et al. 2016) determined whether EVA as measurement tool be able to create shareholder's wealth? After analyzing extant literature (Alipour \& Pejman 2015; Awan, Siddique \& Sarwar 2014; Fayed \& Dubey 2016; Liljeblom \& Maury 2016) concerning EVA, it became evident that the studies obtained mixed results for the role of EVA on true wealth creation of shareholders. From such mixed results, there can be a theoretical argument on the properties of EVA. Many extant studies like (Chetty, Friedman \& Rockoff 2014; Salehi, Enayati \& Javadi 2014) examined the characteristics of EVA, but they also question its utility towards shareholders value.

Signaling Theory: This was initially developed by Ross in 1979. The theory was the result of information asymmetrical in which a condition where the has more information on operation and company's prospect in the future Tambunan (2008, as cited in Mursalim, 2009). Signaling theory accentuated the importance of information issued by the company towards foreign company's investment decision. Information is an important element for investor and other business people since it actually presents past, present and future description, notes or illustration for company's continuity. Complete, relevant, accurate, and meet deadline information is truly needed by an investor in the capital market as an analysis tool to make an investment decision. One of the information types issued by a company which can be a good signal for foreign parties, especially investor is an annual report. Information disclosed in annual report can be an accounting information i.e. information related to the financial statement and non accounting information, that is information which is not related to the financial statement. The annual report should contain relevant information and reveals information considered important to be known by those using the report both external and internal party. All investors need information to evaluate company's relative risk so that able to conduct portfolio diversification and investment combination with risk preference wanted. If a company wanted to get an investor, it had to conduct financial statement disclosure openly and in a transparent way.

\section{RESEARCH METHODS}

\section{Data Collection}

The data for this study were collected from 12 selected banks in Nigeria whose shares were listed on the Nigerian Stock Exchange (NSE) throughout the period of five years from 2014 to 2018 via referring to the audited annual financial reports of the banks from NSE data base and the banks websites. The banks include: United Bank for Africa PLC, First Bank PLC, Union Bank PLC, Zenith International Bank PLC, Diamond Bank PLC, Sky Bank PLC, Eco-bank PLC, Unity Bank PLC, Guaranty Trust Bank PLC, Access Bank PLC, Fidelity Bank PLC, and Sterling Bank PLC. This selection was unbiased because it is believed that the more the number of branches of the branches, the wider the coverage and number of customers, thus necessitated the above selection.

\section{Sampling Design and Model Specification}

Quantitative research approach was employed for the research study. Correlation and simple linear regression methods have been utilized in order to address the objectives of the as well as test the two hypotheses formulated for the study. Financial stability (FS) is the dependent variable which is a factor that investors use to determine whether or not to purchase a stock. While the independent variables employed are earning per share (EPS) and Economic Value Added per share (EVAPS) respectively. In this study, annual market price per share has been use as the proxy of financial stability.

Besides, this study select Earnings per share (EPS) of the banks as the proxy of traditional earnings measures, also called net income per share. This is a market prospect ratio that measures the amount of net income earned per share of stock outstanding. It is the amount of money each share of stock would receive if all of the profits were distributed to the outstanding shares at the end of the year. Earnings per share are also calculation that shows how profitable a company is on a shareholder basis. So a larger company's profits per share can be compared to smaller company's profits per share.

Stewart Stern and company developed the Economic value added (EVA), which is the difference between the firm's after-tax return on capital and the firm's cost of capital. Economic value added is defined as the residual return that subtracts the cost of invested capital from net operating profit after tax (Stewart 1991) EVA is equal to the economic book value of the capital at the beginning of the year and the difference between its return on capital and cost of capital. The formula for calculating EVA is as follows:

$\mathrm{EVA}=$ NOPAT $-\mathrm{k} \times$ Capital

Where, NOPAT means Net operating profits after tax.

$\mathrm{K}$ refers the firms weighted average cost of capital and capital represents equity plus long-term debt of the company at the start of the period.

The following regression model has been developed based on the mentioned variables to assess the objectives of the study: 
$\mathrm{FS}_{\mathrm{i}, \mathrm{t}}=\alpha+\beta_{1} \mathrm{EVAPS}_{\mathrm{i}, \mathrm{t}}+\beta_{2} \mathrm{EPS}_{\mathrm{i}, \mathrm{t}}+\varepsilon$

In this model, $\mathrm{FS}_{\mathrm{i}, \mathrm{t}}$ means Financial stability of an individual bank in a specific time period and EVAPS $_{i, t}$ measures the Economic Value Added of an individual bank in the same time period. $\mathrm{EPS}_{\mathrm{i}, \mathrm{t}}$ represents the Earnings per share of an individual company in the same time period. ' $\alpha$ ' denotes the constant and ' $\varepsilon$ ' represents the error terms.

\section{RESULTS AND DISCUSSION}

\section{Descriptive Statistics}

The table 1 shows the descriptive statistics of the dependent and independent variables of the study.

Table 1: Descriptive Statistics

\begin{tabular}{|c|c|c|c|c|}
\hline Variables & Minimum & Maximum & Mean & $\begin{array}{c}\text { Std } \\
\text { Deviation }\end{array}$ \\
\hline FS & 13.30 & 107.3732 & 41.3732 & 23.8986 \\
\hline EPS & 0.30 & 1.9972 & 1.9972 & 1.0282 \\
\hline EVAPS & 1.42 & 2.9276 & 2.9276 & 1.3310 \\
\hline
\end{tabular}

Source: Researcher Computation using SPSS 17.

Table 1 shows the mean and the extent to which the aggregate values deviate from the mean. The EPS of 1.03 and EVAPS of 1.33 over the five years indicate the consistency of the value of standard deviation. But in relation to the financial stability (FS), a relatively high standard deviation of 23.9 is shown in the five years period.

Table 2: Correlations Matrix

\begin{tabular}{|c|c|c|c|}
\hline & FS & EPS & EVAPS \\
\hline $\begin{array}{c}\text { FS Pearson } \\
\text { correlation } \\
\text { sig (2-tailed) }\end{array}$ & 1 & $\begin{array}{c}0.631^{* *} \\
0.001\end{array}$ & $\begin{array}{c}0.834^{* *} \\
0.000\end{array}$ \\
\hline $\begin{array}{c}\text { EPS Pearson } \\
\text { correlation } \\
\text { sig (2-tailed) }\end{array}$ & $\begin{array}{c}0.631^{* *} \\
0.001\end{array}$ & $\begin{array}{c}1 \\
0.001\end{array}$ & $\begin{array}{c}0.650^{* *} \\
0.000\end{array}$ \\
\hline $\begin{array}{c}\text { EVAPS Pearson } \\
\text { correlation sig (2- } \\
\text { tailed) }\end{array}$ & $\begin{array}{c}0.834 * * \\
0.000\end{array}$ & $\begin{array}{c}0.659 * * \\
0.000\end{array}$ & 1 \\
\hline
\end{tabular}

Source: Researcher Computation using SPSS 17.

***Correlation at significant0.01 level (2-tailed)

The table- 2 above indicated the correlation matrix between financial stability and earnings per share (EPS), and economic value added per share (EVAPS) used in the study. The result have shown that there is a strong, positive and statistically significant relationship for all the variables revealing EVAPS of 0.834 having stronger relationship with FS than that of EPS of 0.631 .

Table 3: Model Summary

\begin{tabular}{|c|c|c|c|c|}
\hline Model & $\mathrm{R}$ & $\begin{array}{c}\text { R Square } \\
\left(\mathrm{R}^{2}\right)\end{array}$ & Adjusted $\mathrm{R}^{2}$ & $\begin{array}{c}\text { Std Error of } \\
\text { Estimate }\end{array}$ \\
\hline 1 & $0.842^{\mathrm{a}}$ & 0.709 & 0.682 & 13.4723 \\
\hline
\end{tabular}

Source: Researcher Computation using SPSS 17.

\section{a. Predictors (Constant) EVAPS, EPS}

In table-3, A strong relationship between financial stability (dependent variable) and independent variables (EPS and
EVAPS) as indicated by the value of $\mathrm{R}$, coefficient of correlation of 0.842 . The coefficient of determination, adjusted R2 is 0.682 which signify that about $31.8 \%$ of the dependent variable is accounted for by the independent variables and the remaining $68.2 \%$ is accounted for by the other variable.

Table 4: Coefficients ${ }^{\text {a }}$

\begin{tabular}{|c|c|c|c|c|c|}
\hline & $\begin{array}{c}\text { Non- } \\
\text { standard } \\
\text { coefficient }\end{array}$ & $\begin{array}{c}\text { Standard } \\
\text { coefficient }\end{array}$ & \multicolumn{3}{|}{} \\
\hline Model & B & Std Error & Beta & T & Sig \\
\hline 1 (Constant) & 4.338 & 6.877 & & 0.631 & 0.535 \\
\hline EPS & 3.584 & 3.520 & 0.154 & 1.018 & 0.320 \\
\hline EVAPS & 13.169 & 2.719 & 0.733 & 4.843 & 0.000 \\
\hline
\end{tabular}

Source: Researcher Computation using SPSS 17.

\section{a. Dependent variable FS}

From table 4, regressions coefficient of EPS 3.584 and EVAPS 13.169 with in corresponding beta coefficient is 0.154 and 0.733 respectively showing that economic value added per share has much influence on the financial stability than earnings per share. This means the EPS has influence but not statistically significant with $32 \%$ which is less than $95 \%$ confidence level. On the other hand, the level of significance of EVAPS is 0.00 which is less than $5 \%$ significant level. Hence it is statistically significant. Therefore, the null hypothesis which states that EVPS has more significant effect on MVPS than EPS is hereby accepted.

\section{CONCLUSION}

This study provides preliminary empirical evidence investigating the impact of earnings performance on financial stability of banks listed on Nigerian stock exchange. It reveals that several factors are probably found to be predictors to explain the impact of earnings performance on financial stability of banks listed on Nigerian stock exchange. The results of study is consistent with the findings of the studies of Sathasivam (2014) and Lehn \& Makhija (1997), which showed that financial stability is more explained by economic value added per share than the conventional accounting measures. Additionally, it is evident that there is a positive relationship between earnings per share, economic value added per share and financial stability of banks listed on Nigerian stock exchange. The outcome of this study also established that earnings per share have influence on financial stability, although the influence is not statistically significant.

The study suggests that there is a vast scope for further researches in this area to find out the factors influencing the financial stability other than the variable used in the study. Moreover, further research can be carried out in the other financial sectors of the economy in Nigeria.

\section{REFERNCES}

[1] Abate, J. A., J. L. Grant \& B. G. Stewart (2004). The EVA style of investing', Journal of Portfolio Management, 30(4), 61-72.

[2] Ahmad, I., Alam, M. S. \& Yameen, M. (2019). A Study of Economic Value Added (EVA) \& Market Value Added (MVA) 
of Hindustan Petroleum Corporation Limited, Global Journal of Economics and Business, Vol. 6, No. 1, 2019, 225-237.

[3] Allen, W. \& Wood, G. (2006). Defining and achieving financial stability, Journal of Financial Stability, June, pp. 152-172.

[4] Alipour, M. \& Pejman, M.E. (2015). The impact of performance measures, leverage and efficiency on market value added: Evidence from Iran. Global Economics and Management Review 20(1): 6-14.

[5] Ani W. U., Ugwunta D. O., Ezeudu I. J., \& Ugwuanyi G. O. (2012). An Empirical assessment of the determinants of bank profitability in Nigeria: Bank Characteristics Panel Evidence. Journal of Accounting and Taxation, 4(3), : 38-43.

[6] Aremu M. A., Ekpo, I. C., \& Moustapha, A. M. (2013). Determinants of Banks' Profitaility in a Developing Economy: Evidence from Nigerian Banking Industry, Interdisciplinary. Journal of Contemporary Research in Business, 4(9).

[7] Awan, A.G., Siddique, K. \& Sarwar, G. (2014). The Effect Of Economic Value Added On Stock Return: Evidence From Selected Companies Of Karachi Stock Exchange. Research Journal of Finance and Accounting 5(23): 140-152.

[8] Azam, A. \& Rasoo, 1. K. (2018). Application of economic value added in the banking sector of Iran, Journal of Money and Economy, 13(3), 291-318.

[9] Biddle, G., Bowen, M. R., \& Wallace, J. (1997). Does EVA beat earnings? - Evidence on associations with stock returns and firm values. Journal of Accounting and Economics, 24(3), 301-336.

[10] Blaise G. \& Kaushik J. (2015). Monetary and economic department, Bank for International Settlements. IFC Bulletin No 31.

[11] Booth, G. G., Broussard, J \& Loistl, O. (1997). Earnings and stock returns: evidence from Germany', The European Accounting Review, 6(4), pp. 589-603.

[12] Brown, L. D. \& Caylor, M. L. (2005). Corporate governance and firm performance, The Accounting Review, 80(2), 1-23.

[13] Chant, J. (2003). Financial Stability as a Policy Goal", in Essays on Financial Stability, Technical Report No. 95, Bank of Canada, September.

[14] Chen, S. and J. L. Dodd (1997). Economic value added: An empirical examination of a new corporate performance measure, Journal of Managerial Issues, 9(3), 318-333.

[15] Chen, S., \& Dodd, J. L. (1997). Usefulness of accounting earnings, residual income, and EVA: A value-relevance perspective. Clarion University. Unpublished Working paper.

[16] Cheng, C. S. A., J. K. Cheung and V. Gopalakrishnan (1993). On the usefulness of operating ilncome, net income and comprehensive income in explaining security returns, Accounting and Business Research, 23(91), 195-203.

[17] Chetty, R., Friedman, J.N. \& Rockoff, J.E. 2014. Measuring the impacts of teachers II: Teacher value- added and student outcomes in adulthood. The American Economic Review 104(9): 2633-2679.

[18] Cihak, M., (2006). Central banks and financial stability: A survey of financial stability reports, Paper presented to the Seminar on Current Developments in Monetary and Financial Law, Washington, D.C., October 23-27.

[19] Copeland, T., Dolgoff, A. \& Moel, A. (2004). The roles of expectations in explaining cross section of stock returns. Review of Accounting Studies, 9, 149-188.

[20] Crockett, A., (1997). Why is financial stability a goal of public policy in Maintaining Financial Stability in a Global Economy?, Symposium Proceedings, Federal Reserve Bank of Kansas City, August, pp. 55-96.

[21] Davis, E. (2001). A Typology of financial instability, Oesterreichische Nationalbank (Central Bank of Austria), Financial Stability Report No. 2, pp. 92-110.

[22] Dodd, J. L., \& Chen, S. (1996). Earnings value added: A new panacea, Business and Economic Review, 42(4), 26-28.
[23] European Central Bank, (2005). Assessing financial stability: Conceptual boundaries and challenges, Financial Stability Review, June, 117-125.

[24] European Central Bank, (2005). Measurement challenges in assessing financial stability, Financial Stability Review, December, 131-141.

[25] European Central Bank, (2007). Progress towards a framework for financial stability assessment, speech by José-Manuel González-Páramo, Member of the Executive Board of the ECB, OECD World Forum on "Statistics, Knowledge and Policy", Istanbul, 28 June.

[26] Ejaz, M., Tashfeen, R., Younas, K. \& Naeem, A. (2018). Economic Value Added or Earnings per Share? An Incremental Content Analysis, Empirical Economic ReviewVol. 1, No. 2 (winter, 2018), 63- 90.

[27] EL Mir, A. and Seboui, S. (2008). Corporate governance and relationship between EVA and created shareholder value. Corporate Governance, 8(1), 46-58.

[28] Ferguson, R., (2003). Should financial stability be an explicit central bank objective?, in Monetary Stability, Financial Stability and the Business Cycle: Five Views, BIS Paper No. 18, September, 7-15.

[29] Fayed, A.M. \& Dubey, S. 2016. An Empirical Study of Impact of EVA Momentum on the Shareholders Value Creation as Compared to Traditional Financial Performance Measures-With Special Reference to the UAE. International Journal of Economics and Finance 8(5): 23.

[30] Financial Stability Board. (2020). COVID-19 pandemic:Financial stability implications and policy measures taken, http://www.fsb.org/terms_conditions/

[31] Foot, M., (2003). What is financial stability and how do we get it? The Roy Bridge Memorial Lecture, Financial Services Authority, April.

[32] Forker, J. \& R. Powell (2004). Does EVA beat earnings? Evidence on associations with stock returns and firm values revisited, Conference paper, presented in EAA Meeting in Prague, 1-3 April.

[33] Frankel, J.A. \& Rose, A.K. (1996). Currency crashes in emerging markets: An empirical treatment. Journal of International Economics 41(3): 351-366.

[34] Freeman, R.E. (1984). Strategic planning: A stakeholder approach. Pitman, Boston.

[35] Gompers, G. A., Ishii, J. A., \& Matrick, A. (2003). Corporate governance and equity prices. The quarterly Journal of Economics, 118, 107-115.

[36] Gray, D. F., Merton, R. C. \& Bodie, Z. (2007). New framework for Measuring and managing macro-financial risk and financial stability, NBER working Paper N0. 13607, November.

[37] Garvey, G. T. \& Milbourn, T. T. (2000). EVA versus earnings: Does is matter which is highly correlated with stock returns? Journal of Accounting Research, 21, 208-231.

[38] Gjesdal, F. (1981). Accounting for stewardship. Journal of Accounting Research, 21, 208-231.

[39] Graham, R. C. \& R. D. King (2000). Accounting practices and the market valuation of accounting numbers: Evidences from Indonesia, Korea, Malaysia, the Philippines, Taiwan and Thailand', The International Journal of Accounting, 35(4), pp. 445-470.

[40] Goetzmann, W. N. \& S. J. Garstka (1999), The Development of Corporate Performance Measure: Benchmarks Before EVA, Yale ICF Working Paper, 99-06, July 12, New Haven: Yale School of Management.

[41] Grant, J. (2003). Foundations of Economic Value Added, 2nd Ed., New York: John Wiley \& Sons.

[42] Günther, T., B. Landrock, T. \& Muche, T. (2000). 'Genwing versus unternehmenswertorientierte performance - Eine Empirische Untersuchung auf Basis der Korrelation von Kapitalmarktrenditen für die Deutsche DAX-100 -Unternehmen' [Profit versus Value Based Performance Measures. An Empirical Investigation Based on the Correlation with Capital 
Market for German DAX-100 Companies], Controlling, 1(2), pp. 69-75 and 2(3), $\quad 129-\quad 134$.

[43] Gupta, V.K. \& Sikarwar, E. (2016). Value creation of EVA and traditional accounting measures: Indian evidence.

International Journal of Productivity and Performance Management 65(4): 436-459.

[44] Hawkins, J. \& Klau, M. (2000). Measuring potential vulnerabilities in emerging market $\quad$ Economies, BIS Working paper N0. 91, October.

[45] Issing, O. (2003). Monetary and financial stability: Is there a trade-off?", in monetary stability, Financial Stability and the Business Cycle: Five Views, BIS Paper No. 18, September, pp. 16-23.

[46] Jensen, M.C. (2001). Value maximization, stakeholder theory, and the corporate objective function. Journal of Applied Corporate Finance 14(3): 8-21.

[47] Jindrichovska, I. (2001). The relationship between accounting numbers and returns: Some empirical evidence from the emerging market of Czech Republic', The European Accounting Review, 10(1), 107-131.

[48] Kanu, C. \& Nwali, A. C. (2019). Financial instabilitiy and performance of banking sectors in Nigeria: An evaluation, African Journal of Accounting Auditing and Finance . January, DOI: $\quad$ 10.1504/AJAAF.2019.099165

[49] Keef, S. P. \& Roush, M. L. (2003). The relationship between economic value added and stock market performance: A theoretical analysis', Agribusiness, 19(2), 245-253.

[50] King, R. D. \& Langli, J. C. (1998). Accounting diversity and firm valuation, The International Journal of Accounting, 33(5), 529-567.

[51] Kramer, J. \& J. Peters (2001). An inter-industry analysis of economic value added as a proxy for market value added, Journal of Applied Finance, 11(1), 41-49.

[52] Konstantinos, N. B. (2018). Assessing bank efficiency and stability, Finance Group, Essex Business School, University of Essex

[53] Kothari, S. P. (2001). Capital markets research in accounting, Journal of Accounting and Economics, 31(1/3), 105-231.

[54] Kothari, S. P. \& Zimmerman, J. L. (1995), 'Price and Return Models', Journal of Accounting and Economics, 20(2), pp. 155192.

[55] Lager, J. (1999), “Monitoring Financial System Stability”, Reserve Bank of Australia Bulletin, October.

[56] Leong, K., Pagani, M. \& Zaima, J. K. (2009). Portfolio strategies using EVA, earnings ratio or book-to-market: Is one best? Review of Accounting and Finance, 8(1), 76-86.

[57] Lehn, K. \& Makhija, J. (1997) Eva, accounting profit and coe turnover: An empirical examination: 1985-1994. Journal of Applied Corporate Finance, 10(2), 90-97.

[58] Liljeblom, E., \& Maury, B. (2016). Shareholder protection, ownership, and dividends: Russian evidence. Emerging Markets Finance and Trade 52(10): 2414-2433.

[59] Maradun, S. M. (2010). The impact of firms characteristics on market value of quoted manufacturing firm in Nigeria. An Unpublished M. Sc. Thesis submitted to the Postgraduate School, Ahmadu Bello University, Zaria.

[60] Milunovich, S. \& A. Tsuei (1996). EVA in the computer industry, Journal of Applied Corporate Finance, 9(2104-115.

[61] Mishkin, F. (1999). Global financial instability: Framework, events, issues, Journal of Economic Perspectives, 13 4), Autumn,. 3-20.

[62] Mishkin, F. (2000). Financial stability and the macro-economy, Central Bank of Iceland Working Paper No. 9, May.

[63] Mursalim. (2009). Economic Value Added (EVA) dan Market Value Added (MVA) dampaknya terhadap Nilai Perusahaan. Jurnal keuangan dan Perbankan, 13(3): 498 - 505.

[64] Myers, R. (1997), Measure for Measure. CFO Magazine, November, 18-23.
[65] Naila T., Ahmad K. \& Mian S. N. (2014). Real earnings management and future performance Global Business Review 16(1) 1-14 SAGE Publications Los Angeles, London, New Delhi, Singapore, Washington DC

[66] Nelson, W. R. \& peril, R. (2005). Selected indicators of financial stability, $4^{\text {th }}$ Joint central Bank Research conference on Risk Measurement and Systematic Risk. ECB Frankfurt Am main, November.

[67] Nuttawat, V., Robin, L. \& Yi, Y. (2008). Econoic value added and sector returms. Asian Academy of Management Journal of Accounting and Finanace, 2(2), 21-41.

[68] Oosterloo, S., Haan, J. \& Jong-A-Pin, R., (2007). Financial stability reviews: A first empirical analysis, Journal of Financial Stability, March, 337-355.

[69] Padoa-Schioppa, T., (2002). Central banks and financial stability: Exploring a land in between, Paper presented at the Second ECB Central banking conference, Frankfurt am Main, 24-25 October.

[70] Priyanka, T. and Sudha, B.(2020). Concept of economic value added and its application in Commercial Banks, International Journal of Scientific \& Technology Research, 9 (03), 1639 -1641.

[71] Rahman, M. M., Moniruzzaman, M. \& Sharif, M. J. (2013) Techniques, motives and controls of earnings management. International Journal of Information Technology and Business Management, 11(1), 22-34.

[72] Roth, K. \& O’Donnell, S. (1996). Foreign subsidiary compensation strategy: An agency theory perspective. Academy of Management Journal 39(3): 678-703.

[73] Sathasivam B. (2014). Firm performance and earnings per share: A study oflisted banks in Sri Lanka. Merit Research Journal of Accounting, Auditing, Economics and Finance Vol. 2(1), 8-11, January. Available online tp://www.meritresearchjournals.org/aaef/index.htm

[74] Salehi, M., Enayati, G. \& Javadi, P.( 2014). The relationship between intellectual capital with economic value added and financial performance. Iranian Journal of Management Studies 7(2): 245.

[75] Schinasi, G., (2004). Defining financial stability, IMF Working Paper No. WP/04/187, October.

[76] Shrikant, K. P. (2017). Economic Value Added and Traditional Accounting Measures for Shareholder's Wealth Creation, Asian Journal of Accounting and Governance 8: 125136.https://doi.org/10.17576/AJAG-2017-08-11)

[77] Sloan, R. G. (1993). Accounting earnings and top executive compensation. Journal of Accounting and Economics, 16(1-3), $55-100$.

[78] Sparling, D. and C. G. Turvey (2003), Further Thoughts on the Relationship Between Economic Value Added and Stock Market Performance, Agribusiness, 19(2), pp. 255-267.

[79] Stewart, G. B. (1991). EVA: fact and fantasy? Journal of Applied Corporate Finance, 7(2), 71- 84

[80] Tisdell, C.A. \& Wilson, C. (2012). Nature-Based Tourism and Conservation: New Economic Insights and Case Studies. Edward Elgar Publishing.

[81] Turvey, C. G., L. Lake, E. Van Duren and D. Sparing (2000), The relationship between economic value added and the stock market performance of agribusiness firms', Agribusiness, 16(4), pp. 399-416.

[82] Vafeas, N., L. Trigeorgis and X. Georgiou (1998). The usefulness of earnings in explaining stock returns in an emerging market: The case of Cyprus', European Accounting Review, 7(1), 105-126.

[83] Worthington, A. C. and T. West (2001), Economic value-added: a review of the theoretical and empirical literature, Asian Review of Accounting, 9(1), 67-86.

[84] Worthington, A. C. and T. West (2004), Australian evidence concerning the information content of economic valueadded, Australian Journal of Management, 29(2201-224. 